\title{
Isolasi Kandungan Senyawa Kimia dari Pakis Simpei (Cibotium barometz) serta Uji Bioaktivitas Antioksidan, Uji Toksisitas (BSLT) dan Antidiabetes
}

\section{Isolation of Chemical Compounds of Pakis Simpei (Cibotium barometz) and Bioactivity Test of Antioxidant, Toxicity (BSLT) and Antidiabetes}

\author{
Sri Hartati ${ }^{1}$, Rugayah ${ }^{2}$, Titien Ngatinem Praptosuwiryo ${ }^{3}$ \\ ${ }^{1}$ Pusat Penelitian Kimia - LIPI, Kawasan PUSPIPTEK Serpong, Tangerang Selatan, Indonesia \\ ${ }^{2}$ Herbarium Bogoriense, Bidang Botani, Pusat Penelitian Biologi - LIPI, Cibinong Science Center, Bogor, \\ Indonesia \\ ${ }^{3}$ Pusat Konservasi Tumbuhan-Kebun Raya Bogor - LIPI, Jl. Ir. H. Juanda No. 13 Bogor, Indonesia \\ Corresponding author: elzariana@yahoo.com
}

\begin{tabular}{l} 
A R T I C L E IN F O \\
\hline Article history \\
Received date :22 December 2015 \\
Revised date : 9 February 2016 \\
Accepted date :10 June 2016 \\
Available online at : \\
http://kimia.lipi.go.id/inajac/index.php \\
Kata kunci: \\
Cibotium barometz, antioksidan, metil \\
dodekanoat, $\beta$-sitosterol, $\beta$-sitosterol- \\
O-glukopiranosida dan 2,3,4,5,6- \\
pentahidroksi sikloheksan asam \\
karboksilat. \\
Keywords: \\
Cibotium barometz L., antioxidant, \\
methyl dodecanoate, $\beta$-sitosterol, $\beta$ - \\
sitosterol-O- glucopyranoside and \\
2,3,4,5,6-pentahydroxy cyclohexane \\
carboxylic acid
\end{tabular}

\section{Abstrak}

Cibotium barometz (L.) J. Sm. (Cibotiaceae) merupakan salah satu jenis tumbuhan paku pohon komoditi ekspor yang memiliki nilai ekonomi tinggi karena kandungan kimianya yang dapat dimanfaatkan sebagai bahan obat tradisional maupun modern. Penelitian ini ditujukan pada isolasi kandungan kimia dan evaluasi anti oksidan, antidiabetes dan toksisitas ekstrak rimpang dan bulu $C$. barometz terhadap larva udang Arthemia salina L. (BSLT). Hasil uji antiokoksidan ekstrak metanol bulu dan rimpang serta hasil fraksionasi dengan menggunakan metoda radical scavenger DPPH (Diphenyl Picryl Hidrazyl), bahwa fraksi etil asetat dan butanol menunjukkan aktivitas berturut-turut dengan $\mathrm{IC}_{50}$ 27,53 dan 46,24 ppm dan ekstrak metanol rimpang dan ekstrak metanol bulu dinyatakan kurang aktif dengan $\mathrm{IC}_{50}$ 183,43 dan 126,10 ppm. Hasil uji toksisitas dengan metoda Brine Shrimp Lethality Test (BSLT) dinyatakan tidak toksik dan hasil uji anti diabetes dengan metoda $\alpha$ glukosidase juga tidak aktif. Hasil isolasi senyawa kimia ekstrak rimpang dan bulu $C$. barometz dengan metoda kromatografi kolom gravitasi dan diidentifikasi berdasarkan data-data spektra IR dan RMI proton dan karbon serta LC-MS, ekstrak $n$-heksana rimpang dan ekstrak metanol bulu $C$. barometz, diperoleh senyawa metil dodekanoat (A), $\beta$-sitosterol (B), $\beta$ sitosterol-O- glukopiranosida (C) dan 2,3,4,5,6-pentahidroksi sikloheksan asam karboksilat (D).

\footnotetext{
Abstract

Cibotium barometz (L.) J. Sm. (Cibotiaceae) is a tree fern which have high economic value as export commodities because of its chemical content that can be used as traditional and modern medicine. This study aim to isolate the chemical compounds and to evaluate the antioxidant, antidiabetic and Brine Shrimp Lethality Test (BLLT) activities of extracts rhizome and hairs of $C$. barometz. The antioxidant activity results using the method of radical scavenger DPPH (Diphenyl Picryl Hidrazyl) in methanol extract of $C$. barometz and rhizome showed that the ethyl acetate and butanol fraction had anti oxidant activity with $\mathrm{IC}_{50} 27.53$ and $46.24 \mathrm{ppm}$ respectively, while the methanol extract of rhizomes and hairs was lest active with $\mathrm{IC}_{50} 183.43$ and $126.10 \mathrm{ppm}$ respectively. The toxicity test using the methode BSLT showed that the extract of C.barometz were no toxic to the shrimp. This extracts also not active as antidiabetes which assayed using $\alpha$-glucosidase inhibition method. Isolation of chemical compounds from rhizomes and fern of $C$. barometz extracts by gravity column chromatography and identification base on data FT-IR spectra, proton and carbon NMR and LC-MS, resulting methyl dodecnoate (A), $\beta$-sitosterol (B), $\beta$-sitosterol- $O$-glucopyranoside $(\mathbf{C})$ and 2,3,4,5,6-pentahydroxy cyclohexane carboxylic acid (D).

(C) 2016 Indonesian Journal of Applied Chemistry. This is an open access article under the CC BY-NC-SA license.
} 


\section{PENDAhUluan}

Cibotium barometz merupakan salah satu jenis tumbuhan paku pohon anggota suku Cibotiaceae $^{[1]}$. Jenis ini termasuk tumbuhan tropik dan subtropik yang tersebar dari India Utara bagian timur sampai Cina bagian selatan, Taiwan, termasuk seluruh daratan Asia Tenggara, dan dari Sumatra, Jawa dan Philippina ke utara hingga Kepulauan Ryukyu $^{[2,3]}$. Jenis ini tumbuh pada lereng-lereng bukit terbuka dan pinggiran-pinggiran sungai di hutan-hutan tropis pada ketinggian 500-800 m dpl dan juga di hutan pegunungan pada ketinggian 1000-1600 m dpl. ${ }^{[1,3,4]}$ Cibotium barometz yang dikenal dengan nama daerah pakis simpei ini telah lama dikenal sebagai bahan obat tradisional dan telah dijadikan sebagai bahan obat modern di berbagai negara seperti Cina, Jepang dan Francis ${ }^{[3]}$ Bulu dan rimpang dari jenis ini berkhasiat sebagai obat hati dan ginjal, memperkuat otot dan tulang belakang, mengurangi ngilu di lutut, mengeluarkan angin dan pembeku darah ${ }^{[3,5]}$. $\mathrm{Qu}(1992)^{[6]}$ dan Yao (1996) ${ }^{[7]}$ melaporkan bahwa di China $C$. barometz dihargai sebagai tanaman kebun atau tumbuhan obat. Diyakini bahwa tumbuhan ini dapat mengobati hati dan ginjal, memperkuat tulang dan otot. Uji-uji fitokimia terhadap $C$. barometz akhir-akhir ini membuktikan bahwa $C$. barometz merupakan bahan obat modern potensial untuk masa depan. Rimpang $C$. barometz sebagai anti imflamasi dan menghilangkan rasa sakit pada encok atau sakit pinggang dan rhematik, ekstrak bulu $C$. barometz potensial sebagai sumber antioksidan dan antibakterial alami. H.-Y. Lai dkk. ${ }^{[8]}$ Lai dan Lim $^{[9]}$ melaporkan bahwa ekstrak metanol C. barometz memperlihatkan kandungan fenol total yang tinggi (di atas $2000 \mathrm{mg}$ GAE/100 g daun segar) dan berpotensi sebagai antioksidan. Hasil uji herbal rimpang $C$. barometz yang dilakukan Wen dkk. ${ }^{[10]}$ memberikan dugaan kuat bahwa $C$. barometz berpotensi untuk terapi antisindrom pernafasan akut yang parah atau severe acute respiratory syndrome (SARS) yang disebabkan oleh coronavirus (SARS-CoV). Wen dkk. ${ }^{[10]}$ melaporkan bahwa ekstrak rimpang kering $C$. barometz memperlihatkan hambatan nyata terhadap aktivitas protease $3 \mathrm{CL}$ SARS-CoV dengan nilai $39 \mathrm{~g} / \mathrm{ml}$. Dari studi baru-baru ini disimpulkan bahwa ekstrak rimpang $C$. barometz berpotensi sebagai obat alternatif untuk mencegah dan mengobati osteoporosis paska-menopous $^{[11]}$. Senyawa hasil isolasi dari ekstrak metanol rimpang $C$. barometz antara lain: cibotiumbaromesides A; cibotiumbaromesides $\mathrm{B}$; cibotiglycerol; $\mathrm{R}=$ 9Z,12Z-Oktadekadienoil. $\quad \mathrm{R}=\quad$ 9Z,12ZOktadekadienoil. Senyawa 2-5 menunjukkan inhibisi osteoclast. ${ }^{[11]}$ Cuong. ${ }^{[12]}$ telah mengisolasi senyawa -senyawa dari ekstrak metanol rimpang $C$. barometz antara lainonitin, onitin glukopiranosa; cyatenosin A; cybotinocyde. $\mathrm{Wu}$ and Yang $^{[13]}$ juga telah mengisolasi senyawa sesquiterpen yang tidak biasa yaitu memiliki inti 1-indone dan asam protacfehuic. Xu dkk. ${ }^{[14]}$ juga telah mengisolasi komponen 4-O-cafeoyl-D-glukopyranosa dari ekstrak rimpang $C$. barometz dengan metoda HPLC. Penelitian ini bertujuan untuk mengisolasi kandungan senyawa-senyawa kimia yang terdapat dalam rimpang dan bulu $C$. barometz yang di ambil dari Propinsi Sumatra Barat. Mengacu dari hasil penelitian tersebut diatas bahwa ekstrak daun $C$. barometz adalah sumber fenol sebagai antioksidan, maka dilakukan uji antioksidan terhadap ekstrak rimpang dan ekstrak bulu $C$. barometz, serta uji bioaktivitas lainnya yaitu uji toksisitas dan antidiabetes.

\section{METODOLOGI PENELITIAN}

\subsection{Bahan dan Peralatan}

\subsubsection{Bahan Tumbuhan}

Bahan rimpang dan bulu C. barometz. dikumpulkan pada bulan September 2013 dari hutan sekunder di dua lokasi di Kabupaten Lima Puluh Kota, Prop. Sumatra Barat, yaitu dari Bukit Soriak, Jorong Tarantang, Nagari Tarantang, Kec. Harau dan Bukit Sikek, Jorong Air putih, Nagari Sari Lamak, Kec. Harau. Jenis dideterminasi dengan menggunakan kunci identifikasi jenis untuk tumbuhan paku pohon menurut Holttum (1963) dan dicocokkan dengan spesimen yang tersimpan di Herbarium Bogoriense (BO). Spesimen bukti disimpan di Herbarium Kebun Raya Bogor (BOHB).

\subsubsection{Bahan Kimia}


Bahan kimia yang digunakan adalah pelarut organik $n$-heksana, etil asetat, metanol, $n$-butanol dan diklorometan teknis yang didestilasi. 1,1-difenil-2-pikrilhidrazil (DPPH) dari Sigma, Dimetil sulfoksida (DMSO) EMerck, $\mathrm{CDCl}_{3}$, Silika gel $\mathrm{G}_{60}$ 70-230 mesh EMerck 1.07734 Plat silika gel $\mathrm{GF}_{254}$ E- Merck 05554, Sephadex LH-20 Amersham.

\subsubsection{Peralatan}

Spektrofotometer UV-Vis Merck Hellet Pakard (HP) 8453, FT-IR Prestige-21, Shimadzu, Spektroskopi RMI $500 \mathrm{MHz}$ Inova Plus, Unity.

\subsection{Metode}

\subsubsection{Metode Isolasi}

Bahan rimpang $C$. barometz yang telah kering digiling atau dihaluskan dengan grinder lalu di timbang, selanjutnya di masukkan kedalam maserator. Sampel dalam maserator ditambahkan metanol teknis (hasil destilasi) sampai terendam. Setelah 24 jam filtrat disaring diuapkan dalam vakum rotary evaporator, selanjutnya residu direndam ulang sampai filtrat jernih atau diperkirakan ekstrak sudah terekstrasi maksimal kurang lebih 5 kali maserasi. Ekstrak yang di peroleh di kumpulkan kemudian di timbang. Ekstrak metanol yang diperoleh dilakukan partisi, pertama dengan pelarut $n$-heksana (teknis hasil destilasi) dikocok dengan air (1 : 1) di kocok dalam corong pisah kemudian didiamkan sampai terpisah 2 fase ( air dan $n$-heksana), fase bawah (air) dipisahkan dari $n$-heksana. Selanjutnya pada fase air ditambahkan kembali $n$-heksana baru, dilakukan proses seperti diatas sampai jernih atau diperkirakan senyawa non polar sudah terekstraksi maksimal ( $3 \mathrm{~s} / \mathrm{d} 5 \mathrm{x}$ partisi). Fraksi $n$-heksana yang diperoleh di gabung selanjutnya diuapkan, dan akan diperoleh fraksi $n$-heksana. Residu air sisa $n$-heksana selanjutan di partisi dengan etil asetat (hasil destilasi) (etil asetat: air $=1: 1$ ) dengan perlakuan yang sama seperti diatas akan diperoleh fraksi etil asetat. Residu air sisa etil asetat selanjutan di partisi dengan $n$-butanol ( -butanol : air $=1: 1$ ) dengan perlakuan yang sama seperti diatas, diperoleh fraksi $n$-butanol. Residu akhir air kemudian dikeringkan di oven vacum $50^{\circ} \mathrm{C}$ akan diperoleh fraksi air. Masing-masing fraksi (n-heksana, etil asetat , $n$-butanol dan air) yang diperoleh ditimbang untuk selanjutnya dilakukan fraksionasi dengan metoda kromatografi kolom dengan fase diam silika gel $\mathrm{G}_{60}$ E Merck 1.07734 (0.0063 - 0,200 mm). Bagan Isolasi dapat dilihat di Gambar 1.Ekstrak metanol dan hasil fraksionasi dilakukan uji antioksidan, toksisitas dan uji antidiabetes.

\subsubsection{Isolasi senyawa rimpang $C$. barometz dalam fraksi $n$-heksana}

Isolasi rimpang $C$ barometz fraksi $n$ heksana hasil partisi ekstrak metanol dilakukan dengan cara fraksionasi dengan metoda kolom kromatorafi dengan fasa diam silika gel G60 ukuran sedang $(0,062-0,200 \mathrm{~mm})$ sebagai fasa gerak dievaluasi dengan pelarut $n$-heksana, etil asetat dan metanol secara gradient, fraksi-fraksi yang diperoleh masing-masing dipekatkan atau dievaporasi dengan vacuum rotary evaporator pada temperatur $50^{\circ} \mathrm{C}$. Fraksi-fraksi pekat tersebut dikumpulkan selanjutnya masingmasing dilakukan KLT. Hasil KLT dengan penampakan bercak yang sama di gabung atau dikelompokkan. Hasil pengamatan KLT dari fraksi 17 sampai fraksi 21 umumnya berupa minyak, namun hanya terlihat 1 (satu) bercak yaitu pada fraksi 18 dan fraksi 20. Bercak tersebut kemudian digabung selanjutnya dilakukan pengamatan TLC dua dimensi, dari pengamtan KLT dua dimensi menunjukkan satu bercak, selanjutnya dilakukan pengukuran dengan FT-IR, RMI proton dan karbon. Dari hasil isolasi tersebut dinamakan senyawa $\mathbf{A}$. Dari fraksi 31 sampai fraksi 69 fraksi campuran ini terdapat endapan putih, dimana endapan putih sukar larut di pelarut methanol sedangkan campuran senyawa lainnya mudah larut. Kemudian dilakukan pencucian secara dekantasi dengan pelarut metanol sampai endapan putih terpisah dari senyawa lainnya. Selanjutnya endapan dikeringkan dan filtratnya diuapkan, masing di KLT dan ditimbang berat keringnya. Hasil KLT yang berupa endapan putih diperkirakan murni disebut sebagai senyawa B. Pada fraksi 22 terdapat koloid berwarna putih dimana koloid tersebut sukar larut dengan pelarut $n$-heksana, etil asetat dan sedikit larut di pelarut metanol, maka dilakukan dekantasi dengan pelarut-pelarut tersebut.Hasil 
J.Kim.Terap.Indones., 18(1),

pp. 1-10, June 2016

dekantasi kemudian dilakukan KLT, karbon, FT-IR dan LC-MS. Selanjutnya dikeringkan selanjutnya di timbang dan di dianalisis berdasarkan data-data spektra dari hasil pengkuran spektroskopi RMI proton,
p-ISSN: 0853-2788, e-ISSN: 2527-7669 Accreditation number : 540/AU1/P2MI LIPI/06/2013 dielusidasi berdasarkan data-data tersebut dan hasil analisis disebut senyawa $\mathbf{C}$.

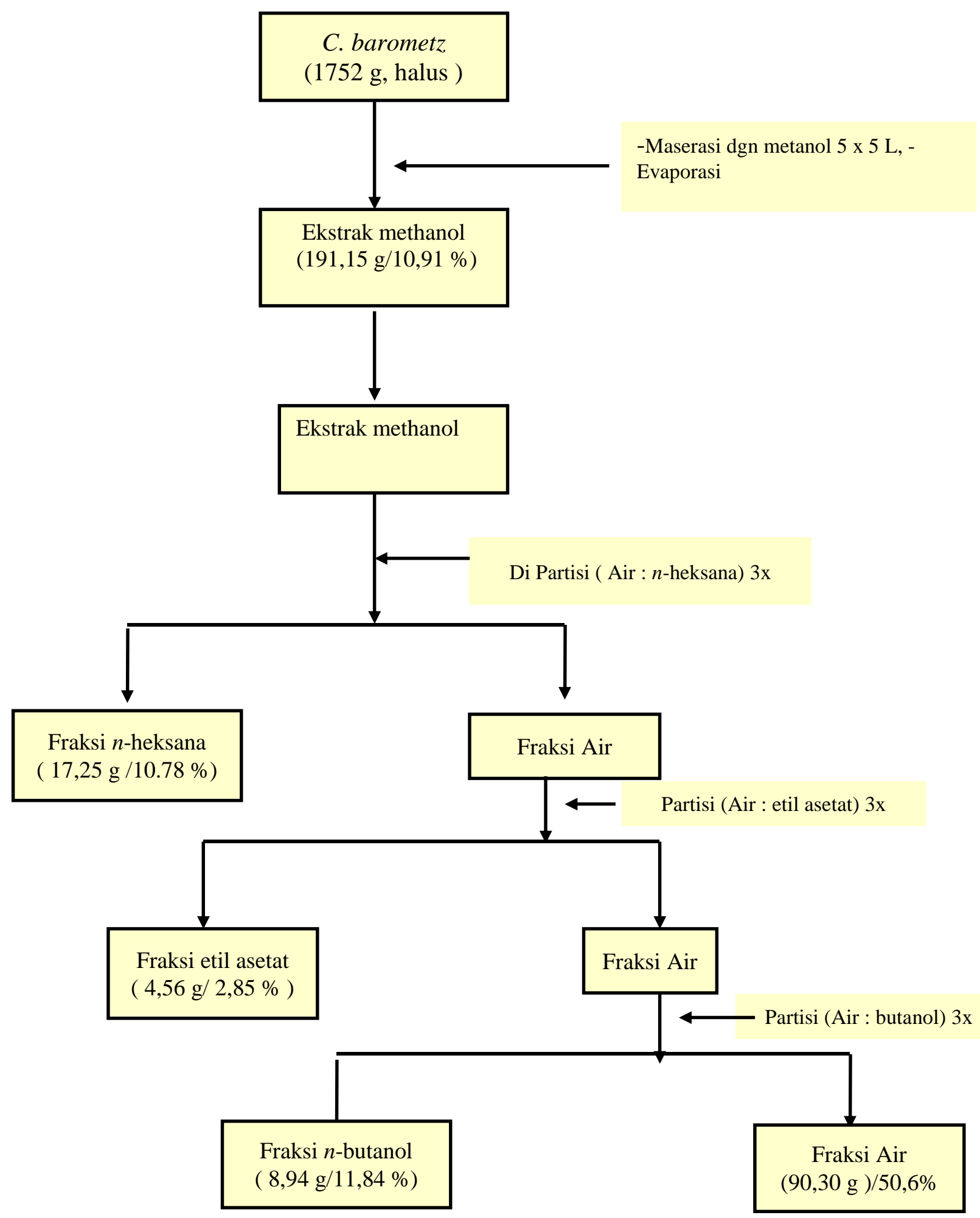

Gambar 1.Bagan alir ekstraksi dan partisi Cibotium barometz 


\subsubsection{Isolasi senyawa kimia dari ekstrak metanol bulu Cibotium barometz.}

Sampel bulu $C$. barometz di timbang selanjutnya dimaserasi dengan metanol untuk diambil ekstraknya, ekstrak yang diperoleh dikumpulkan selanjutnya dipekatkan dengan vacum rotary evaporator. Ekstrak pekat yang diperoleh di kumpulkan dan ditimbang.Karena ekstrak metanol hasil maserasi tidak banyak, maka tidak dilakukan partisi dengan pelarut $n$ heksana, etil asetat , $n$-butanol dan air. Hasil ekstrak metanol kasar (crude) selanjutnya dilakukan fraksionasi untuk memisahkan fraksi atau komponen-komponennya dengan metoda kromatografi kolom gravitasi dengan fasa diam silika gel G60 ukuran sedang $(0,062-0,200 \mathrm{~mm})$ dengan eluen $n$-heksana, etil asetat dan metanol secara gradien. Hasil fraksionasi dalam fraksi 17 dan fraksi 19 terdapat edapan putih kemudian pada keduanya dilakukan dekantasi, sehingga diperoleh endapan murni yang dapat di lihat dari hasil KLT. Untuk selanjutnya dari fraksi 17 diperoleh serbuk kuning pucat disebut senyawa $\mathbf{D}$ dan dari fraksi 19 diperoleh serbuk putih disebut senyawa E. Keduasenyawa tersebut di elusidasi berdasarkan data-data spektra hasil pengukuran spektroskopiRMI proton dan karbon, FT-IR dan LC-MS.

\subsubsection{Uji Anti Oksidan}

Pengujian aktivitas antioksidan dilakukan terhadap ekstrak metanol bulu $C$. barometz, ekstrak metanol rimpang C. barometz, fraksi fraksi $n$-heksana, etil asetat, air dan $n$-butanol rimpang dengan menggunakan metoda radical scavenger DPPH (Diphenyl Picryl Hidrazyl) ( Yen \& Chen, 1995) ${ }^{[15]}$ yang dimodofikasi oleh Artanti, 2003) $)^{[16]}$. Senyawa pembanding sebagai blangko positip adalah kuercetin. Langkah-langkah pengujian dilakukan sebagai berikut : cantoh yang akan diuji dibuat larutan dengan pelarut DMSO pada konsentrasi 10 ppm; 50 ppm; 100 ppm dan 200 ppm. Selanjutnya masing-masing ekstrak ditambahkan DPPH kemudian diinkubasi pada temperatur $37^{\circ} \mathrm{C}$ selama 30 menit. Perubahan warna yang terjadi pada DPPH diukur dengan spektrofotometer pada panjang gelombang 515 nm. Nilai serapan larutan DPPH terhadap sampel tersebut dinyatakan dengan persen inhibisi (\% inhibisi) yang dapat dihitung dengan rumus persamaan 1 .

$\%$ Inhibisi $=\frac{(\text { Abs kontrol }- \text { Abs sampel })}{\text { Abs kontrol }} 100 \%$ (1)

Keterangan:

$A b s_{\text {kontrol }}=$ Absorbansi kontrol setelah 30 menit

$A b s_{\text {sampel }}=$ Absorbansi sampel setelah 30 menit

\subsubsection{Uji Brine Shrimp Lethality Test (BSLT)} (Meyer et al., 1982) ${ }^{[17]}$

Telur A. salina Leach diinkubasi dalam air laut selama 48 jam dan menetas menjadi larva udang. Sebanyak 10 larva dimasukkan kedalam microplate kemudian ditambahkan ekstrak yang dilarutkan kedalam air laut dengan konsentrasi 10, 100 dan 1000 ppm, diinkubasi selama 24 jam. Toksisitas diukur berdasarkan jumlah larva A. salina yang mati setelah inkubasi. $\mathrm{LD}_{50}$ adalah konsentrasi sampel yang diperlukan sebagai penyebab 50\% kematian larva. Suatu zat dikatakan aktif atau toksik bila nilai $\mathrm{LD}_{50}<1000 \mathrm{~g} / \mathrm{mL}$. ${ }^{[18]}$

\subsubsection{Uji Antidiabet ( $\alpha$-glukosidase) ( Kim Y- $\mathrm{M}$, et al, 2005) $)^{[19]}$}

Sebanyak $\quad 0,25 \quad \mathrm{mg} \quad \alpha$-glukosidase dilarutkan dalam $10 \mathrm{~mL}$ buffer fosfat $(\mathrm{pH} 7)$ yang mengandung $20 \mathrm{mg}$ bovine serum albumin. Larutan enzim di encerkan 10 kali sebelum di gunakan. Sistem reaksi enzim terdiri atas campuran 250 L $20 \mathrm{mM}$ p-nitro phenil- $\alpha$ glukopiranoside, $495 \mathrm{~L} 100 \mathrm{nM}$ buffer fosfat $(\mathrm{pH} 7)$ dan 5 L larutan sampel dalam DMSO ( kadar $1 \%, 0.5 \%$, dan $0.25 \%$ ). Campuran reaksi diinkubasi pada $37^{\circ} \mathrm{C}$ selama 5 menit, selanjutnya pada campuran ditambahkan 250

L larutan enzim dan diinkubasi selama 15 menit. Reaksi enzim dihentikan dengan penambahan $1 \mathrm{~mL} 200 \mathrm{mM} \mathrm{Na} \mathrm{CO}_{3}$. Senyawa p-nitrophenol sebagai hasil reaksi diukur 
dengan membaca absorbansi campuran reaksi pada $\lambda 400 \mathrm{~nm}$. Sebagai kontrol positif, digunakan larutan 1\% kuercetin. Ekstrak dinyakan aktif apabila nilai $\mathrm{IC}_{50}<25 \mathrm{ppm}^{[20]}$.

\section{HASIL DAN PEMBAHASAN}

Hasil maserasi dengan metanol (lihat Gambar 1) dari sampel rimpang $C$. barometz $1753 \mathrm{~g}$, diperoleh 191,15 g (10,91\%) ekstrak metanol. Dari $160 \mathrm{~g}$ ekstrak metanol yang di partisi diperoleh 17,25 g (10,78\%) ekstrak $n$ heksan; 4,56 g (2,85\%) ekstrak etil asetat; 18,94 g $(11,84 \%)$ ekstrak $n$-butanol dan 90,30 g $(50,60 \%)$ ekstrak air.

\subsection{Hasil Uji Anti Oksidan}

Hasil uji antioksidan dari sampel sampel ekstrak metanol $C$. barometz rimpang dan bulu serta hasil partisi ekstrak metanol rimpang yaitu fraksi $n$-heksana, etil asetat, $n$ butanol dan fraksi air dengan metoda DPPH, dapat dilihat pada Tabel 1. Hasil fraksi etil asetat dan fraksi butanol menunjukkan aktivitas yang sedang dengan $\mathrm{IC}_{50}$ berturut-turut 27,53 dan 46,24 ppm dan ekstrak metanol rimpang dan ekstrak metanol bulu dinyatakan kurang aktif dengan $\mathrm{IC}_{50} 183,43$ dan 126,10 ppm.

Tabel 1.Data hasil pengujian antioksidan ekstrak metanol bulu dan ekstrak metanol rimpang serta fraksi $n$-heksana, etil asetat, $n$ - butanol dan ar rimpang $C$. barometz.

\begin{tabular}{clc}
\hline No & \multicolumn{1}{c}{ Sampel } & LC 5 ( ppm) \\
\hline & Blangko (Vitamin C) & 4,17 \\
1 & Ekstrak metanol rimpang & 183,43 \\
2 & Ekstrak metanol bulu & 126,09 \\
3 & Fraksi $n$-heksana rimpang & 245,96 \\
4 & Fraksi etil asetat rimpang & $\mathbf{2 7 , 5 3}$ \\
5 & Fraksi $n$-butanol rimpang & $\mathbf{4 6 , 2 4}$ \\
6 & Fraksi air rimpang & 206.08 \\
\hline
\end{tabular}

\subsection{Hasil Uji BSLT}

Dari hasil pengamatan uji toksisitas dengan menggunakan larva udang Artemia salina Leach menunjukkan ekstrak-ekstrak metanol bulu dan rimpang $C$. baromezt dan hasil fraksionasi $n$-heksana, etil asetat, $n$ - butanol dan air dapat dilihat pada Tabel 2. Dari data tersebut dapat dilihat bahwa $\mathrm{LC}_{50}$ yang dibawah $(<1000 \mathrm{ppm})$ adalah fraksi etil asetat dan fraksi butanol dari rimpang $C$. baromezt dengan $\mathrm{LC}_{50}$ masing-masing 724 dan 955 ppm. Bahwa ekstrak dinyatakan toksit bila $\mathrm{LC}_{50}<$ 1000 ppm jadi fraksi etil asetat dan fraksi butanol dapat dikatakan sedikit toksik. Bila dibandingkan dengan ekstrak metanol bulu dan rimpang $C$. baromezt serta fraksi $n$-heksana dan fraksi $n$-butanol rimpang dinyatakan tidak toksik karena $\mathrm{LC}_{50}$ masing-masing diatas (>1000 ppm).

Tabel 2. Data hasil pengamatan Uji BSLT ekstrak metanol bulu dan ekstrak metanol rimpang serta fraksi $n$-heksana, etil asetat, $n$ - butanol dan air rimpang $C$. barometz.

\begin{tabular}{llc}
\hline No & \multicolumn{1}{c}{ Sampel } & LC50 $(\mathbf{p p m})$ \\
\hline 1 & Ekstrak metanol rimpang & 1513,56 \\
2 & Ekstrak metanol bulu & 20417.37 \\
3 & Fraksi $n$-heksana rimpang & 1995.26 \\
4 & Fraksi etil asetat rimpang & 724.43 \\
5 & Fraksi $n$-butanol rimpang & 954.99 \\
6 & Fraksi air rimpang & 1995.26 \\
\hline
\end{tabular}

\subsection{Hasil Uji Antidiabetes}

Dari hasil pengamatan uji antidiabetes dengan metoda $\alpha$-glukosidasemenunjukkan ekstrak-ektrak metanol rimpang dan bulu $C$. barometz dan hasil fraksionasi $n$-heksana, etil asetat, $n$-butanol dan air dapat dilihat pada Tabel 3. Dari data tersebut dapat dilihat bahwa $\mathrm{IC}_{50}$ masing-masing menunjukkan aktivitas > 25 ppm yaitu 203,60; 256,68; 155,60; 192,55; 197,32 dan 345,97 ppm. Jadi dapat dinyatakan bahwa ekstrak metanol rimpang dan bulu $C$. barometz serta hasil fraksionasinya tidak aktif sebagai antidiabetes.

Tabel 3.Hasil pengamatan uji Antidiabetes ( $\alpha$ Glukodidase) ekstrak rimpang dan bulu serta fraksi $n$-heksana, etil asetat, $n$ butanol dan air rimpang $C$. barometz.

\begin{tabular}{clc}
\hline No & \multicolumn{1}{c}{ Sampel } & LC50 $(\mathbf{p p m})$ \\
\hline & Blangko pelarut & - \\
1 & Ekstrak metanol rimpang & 203,60
\end{tabular}


J.Kim.Terap.Indones., 18(1),

pp. 1-10, June 2016

\begin{tabular}{llc}
2 & Ekstrak metanol bulu & 256,68 \\
3 & Fraksi $n$-heksana rimpang & 155,60 \\
4 & Fraksi etil asetat rimpang & 192,549 \\
5 & Fraksi $n$-butanol rimpang & 197,317 \\
6 & Fraksi air rimpang & 345,968 \\
\hline
\end{tabular}

\subsection{Senyawa A(Metil dodekanoat)}

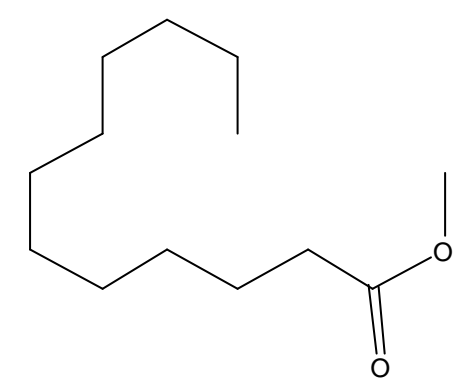

Senyawa $\mathbf{A}=$ metil dodekanoat

Senyawa A berbentuk minyak warnanya bening/jernih, diisolasi dari fraksi $n$-heksana rimpang $C$. barometz melalui proses pemurnian secara kolom kromatografi. Hasil pengamatan IR (KBr) menunjukkan adanya gugus karbonil ester jenuh $(-\mathrm{C}=\mathrm{O})$ pada serapan bilangan gelombang (v)1743 $\mathrm{cm}^{-1}$ (tajam); menunjukkan adanya ikatan $-\mathrm{C}-\mathrm{H}$; $-\mathrm{CH}_{3}$ alifatik pada daerah serapan 2852; 2922 dan $3005 \mathrm{~cm}^{-1}$ (tajam). Dari hasil pengukuran massa $[\mathrm{m} / \mathrm{z}] 215,347$ $\left[\mathrm{M}+\mathrm{H}^{+}\right]$dengan rumus molekul $\mathrm{C}_{13} \mathrm{H}_{26} \mathrm{O}_{2}$. Hasil pengamatan spektrum NMR proton ${ }^{1} \mathrm{H}(500$ $\mathrm{MHz})$ menunjukkan adanya gugus metil triplet $\left(\mathrm{CH}_{3}-\mathrm{CH}_{2}-\right)$, triplet pada daerah pergeseran kimia $(\delta)$ 0,86 ppm yang didukung oleh spektrum RMI karbon ${ }^{13} \mathrm{C}(125 \mathrm{MHz})$ pada pergeseran kimia 14,26 ppm, menunjukkan adanya gugus metoksi atau metil ester $\left(\mathrm{CH}_{3}-\mathrm{O}\right)$; pada pergeseran kimia 3,65 ppm didukung oleh karbon NMR pada $\delta 51,62$ ppm,menunjukkan adanya 2 gugus metan $\left(-\mathrm{CH}_{2}\right)$ triplet pada $\delta$ 1,60 dan 2,39 ppm; adanya metilen yang bertetangga dengan karbonil ester $(\mathrm{H}$ pada $\mathrm{C}-2$ dan $\mathrm{H}$ pada C-3) didukung oleh RMI karbon pada $\delta 34,28$ dan 34,20 ppm, menunjukkan adanya kelompok gugus-gugus metan yang tumpang tindih $\left(-\mathrm{CH}_{2}-\mathrm{CH}_{2}-\right)$ pada daerah pergeseran kimia rentang 1,23 - 1,28 ppm (16 H) dan rentang 29,30 - 29,82 ppm untuk Skarbon. Adanya gugus karbonil ditunjukkan pada $\delta 174,62$ ppm. Dari hasil prediksi penggambaran struktur dengan chem draw dan dengan prediksi angka-angka $\delta$ proton dan karbon serta sifat fisik dapat disimpulkan bahwa senyawa $\mathbf{A}$ adalah metil dodekanoat. Hasil studi beberapa pustaka tentang isolasi dari C. barometz, belum ada senyawa tersebut yang dilaporkan atau ditemukan dari tumbuhan ini. Senyawa metil dodekanoat dalam C. barometz ini pertama kali dilaporkan. Metil dodekanoat dialam biasanya terdapat pada buah anggur, melon, nenas, black berry, cabe merah, dan buah-buahan lainnnya. Nama lain metil dodekanoat adalah metil laurat (DNP. 2015).

\subsection{Sernyawa B. $(\beta$-sitosterol)}

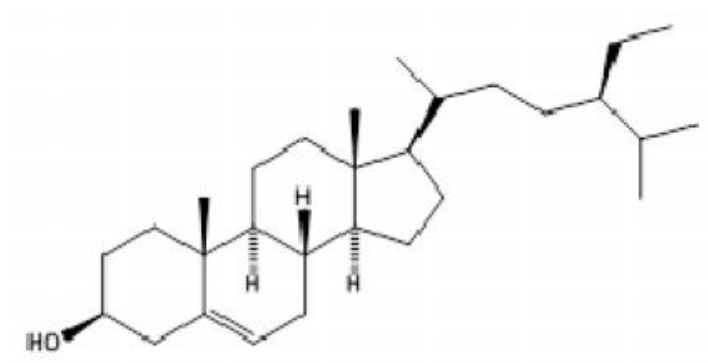

Senyawa $\mathbf{B}=\beta$-sitosterol

Senyawa B diisolasi dari fraksi $n$-heksana rimpang $C$. barometz. Hasil pengamatan awal sifat-sifat fisika, warna putih dan bentuk serbuk sukar larut dalam pelarut polar dan hasil KLT dibandingkan dengan stándar $\beta$-sitosterol menunjukkan kesamaan nilai $\mathrm{Rf}$ dan warna bercak.

Senyawa B dapat ditetapkan sebagai $\beta$ sitosterol. Senyawa $\beta$-sitosterol dan stigmasterol adalah senyawa yang sangat umum ditemukan dari bahan alam tumbuhan, tetapi $\beta$ sitosterol dari $C$. barometz baru pertama kali dilaporkan.

\subsection{Senyawa C $(\beta$-sitosterol $\quad O$ - glukopiranosida)}




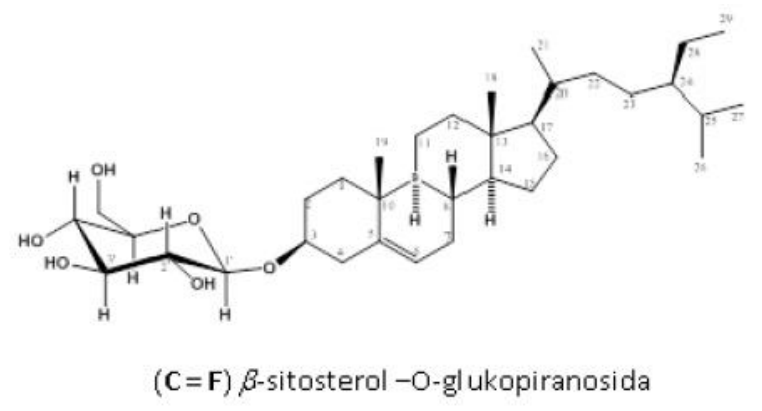

Senyawa C yang diisolasi dari fraksi $n$ heksana rimpang $C$. barometz, merupakan serbuk putih sukar larut dipelarut-pelarut $n$ heksana, etil asetat dan metanol. Jika dilarutkan berbentuk koloid. Hasil pengukuran massa (LC$\mathrm{MS} / \mathrm{m} / \mathrm{z}$ ) menunjukkan berat massa molekul adalah $577\left[\mathrm{M}+\mathrm{H}^{+}\right]$dengan rumus molekul $\mathrm{C}_{35} \mathrm{H}_{6} \mathrm{O}_{6}$.

Dari hasil pengukuran IR $[\mathrm{KBr}]$ menunjukkan adanya gugus-gugus hidroksi ($\mathrm{OH})$ pada serapan bilangan gelombang ( $v)$ 3194- 33-56 $\mathrm{cm}^{-1}$. Hal ini menunjukkan adanya gugus metil $\left(-\mathrm{CH}_{3}\right)$ dan metilen $\left(=\mathrm{CH}_{2}\right)$ pada daerah serapan 2872 dan $2933 \mathrm{~cm}^{-1}$. Hasil pengamatan spektrum RMI proton ${ }^{1} \mathrm{H}$ dan karbon (Tabel. 4) dalam pelarut DMSO $\mathrm{D}_{6}(500$ $\mathrm{MHz}$ ) menunjukkan sinyal-sinyal karakteristik dari 3 gugus metil steroid (metil skuder) pada $\delta$ $0,80 \mathrm{ppm}(3 \mathrm{H}, d, J=3,2 \mathrm{~Hz}) ; 0,83 \mathrm{ppm}(3 \mathrm{H}, d$, $J=3,2 \mathrm{~Hz})$ dan $0,90 \mathrm{ppm}(3 \mathrm{H}, s)$, dan proton metin pada $\delta 5,33 \mathrm{ppm}$ adalah/ merupakan proton ikatan rangkap pada C6.

Adanya proton metin pada $\delta 3,45$ ppm $(1 \mathrm{H}, m)$ menunjukkan adanya proton pada C-3 pengikat oksigen yang menjembatani gugus gula dengan steroid. Hal ini menunjukkan ciri glikosida dengan adanya proton anomerik pada $\delta$ 4,22 ppm $(1 \mathrm{H}, d, J=7,8 \mathrm{~Hz})$ dan karbon glikosidik pada $\delta 100,77 \mathrm{ppm}$.

Dari hasil penyusunan spektra RMI proton, karbon satu dan dua dimensi, korelasi HMQC dan HMBC dapat disimpulkan bahwa senyawa $\mathbf{C}$ adalah suatu glikosida steroid yaitu $\beta$-sitosterol glukopiranosida. Senyawa $\beta$ sitosterol-O-glukopiranosida ini juga baru pertama kali dilaporkan dalam C. barometz.

\subsection{Senyawa D $(2,3,4,5,6$-pentahidroksi}

Accreditation number : 540/AUI/P2MI LIPI/06/2013

\section{sikloheksan asamkarboksilat)}

Senyawa berupa serbuk kuning pucat, hasil pengukuran LC-MS $(\mathrm{m} / \mathrm{z})$ menunjukkan massa $=192$ dengan rumus molekul $\mathrm{C}_{7} \mathrm{H}_{12} \mathrm{O}_{6}$. Dari hasil pengukuran IR ( $\mathrm{KBr})$ terlihat adanya gugus hidroksi $(-\mathrm{OH})$ pada daerah serapan dengan bilangan gelombang 3560; 3456; 3313; dan $3250 \mathrm{~cm}^{-1}$ (tajam). Hal ini menunjukkan adaya gugus karbonil $(-\mathrm{C}=\mathrm{O})$ pada daerah serapan $v 1791 \mathrm{~cm}^{-1}$ (tajam), dengan puncakpuncak serapan tajam pada daerah serapan $v$ berkisar antara $1000-1320 \mathrm{~cm}^{-1}$ yang menujukkan adanya vibrasi regang gugus $-\mathrm{C}-\mathrm{O}$ dari alkohol dan asam karboksilat.

Tabel 4. Data NMR Proton, Karbon dan HMBC Senyawa C

\begin{tabular}{|c|c|c|c|}
\hline No & $\delta^{1} \mathbf{H}(\mathrm{ppm})$ & $\delta^{13} \mathbf{C}(\mathbf{p p m})$ & HMBC \\
\hline 1 & $1,78(\mathrm{~m}) ; 1,80(\mathrm{~m})$ & 36,86 & \\
\hline 2 & $1,51(\mathrm{~m})$ & 31,41 & \\
\hline 3 & $3,45(\mathrm{~m})$ & 75,49 & \\
\hline 4 & $\begin{array}{l}2,36(d, d ; J 2,35 ; \\
2,35 \mathrm{~Hz})\end{array}$ & 38,31 & \\
\hline 5 & - & 140,6 & \\
\hline 6 & $5,33(b)$ & 121,27 & $\begin{array}{l}\text { C-1, C-4, } \\
\text { C-7, C-8 } \\
\text { C- } 10\end{array}$ \\
\hline 7 & 1,38 (m); 1,40 (m) & 31,44 & \\
\hline 8 & 1,47 (b) & 31,41 & \\
\hline 9 & 0,99 (b) & 49,62 & \\
\hline 10 & - & 36,23 & \\
\hline 11 & $1,36(\mathrm{~m}) ; 1,51(\mathrm{~m})$ & 20,62 & \\
\hline 12 & $1,16(\mathrm{~m}, \mathrm{~b})$ & 39,25 & \\
\hline 13 & - & 41,88 & \\
\hline 14 & $1,09(m)$ & 56,20 & \\
\hline 15 & $1,53(\mathrm{~m})$ & 23,91 & \\
\hline 16 & $1,78(\mathrm{~m}) ; 1,63(\mathrm{~m})$ & 29,29 & \\
\hline 17 & $1,03(m)$ & 55,43 & \\
\hline 18 & $0,65(s)$ & 11,72 & $\begin{array}{l}\text { C-13, C- } \\
14, \text { C-17 }\end{array}$ \\
\hline 19 & $0,95(s)$ & 18,95 & $\begin{array}{l}\text { C-5, C-7, } \\
\text { C-8, C-9 }\end{array}$ \\
\hline 20 & $1,80(m)$ & 36,86 & \\
\hline 21 & $0,90(s)$ & 18,65 & $\begin{array}{l}\text { C-15,C- } \\
17, \text { C-21 }\end{array}$ \\
\hline 22 & $1,02(m)$ & 33,36 & \\
\hline 23 & $1,15(\mathrm{~m})$ & 25,41 & \\
\hline 24 & $0,91(s)$ & 45,15 & \\
\hline 25 & $1,63(\mathrm{~m})$ & 28,70 & \\
\hline 26 & $0,80(d, J=3,2 \mathrm{~Hz})$ & 19,14 & $\begin{array}{l}\text { C-24, C- } \\
25, C-27\end{array}$ \\
\hline 27 & $0,83(d, J=3,2 \mathrm{~Hz})$ & 19,76 & $\mathrm{C}-26, \mathrm{C} 29$ \\
\hline 28 & $1,25(\mathrm{~m})$ & 22,63 & \\
\hline 29 & $0,82(t)$ & 11.82 & $\begin{array}{l}\text { C-26, C- } \\
28\end{array}$ \\
\hline $1^{\prime}$ & $4,22(d, J=7,8 \mathrm{~Hz})$ & 100,77 & C-2', C-3' \\
\hline
\end{tabular}


J.Kim.Terap.Indones., 18(1),

pp. 1-10, June 2016

\begin{tabular}{llll}
$2^{\prime}$ & $3,11(\mathrm{~m})$ & 76,79 & $\mathrm{C}^{\prime}{ }^{\prime}$ \\
$3^{\prime}$ & $3,47(\mathrm{~m})$ & 76,91 & $\mathrm{C}^{\prime}, \mathrm{C}^{\prime}{ }^{\prime}$ \\
$4^{\prime}$ & $3,06(\mathrm{~m})$ & 70,11 & \\
$5^{\prime}$ & $3,47(\mathrm{~m})$ & 76,91 & \\
$6^{\prime}$ & $3,64(\mathrm{~m}) ; 3,39(\mathrm{~m})$ & 61,10 & $\mathrm{C}^{\prime}{ }^{\prime}$ \\
\hline
\end{tabular}

Hasil pengukuran RMI proton ${ }^{1} \mathrm{H}$ dalam pelarut metanol $\left(\mathrm{CD}_{3} \mathrm{OD}, 500 \mathrm{MHz}\right) \quad$ (Tabel. 5) menunjukkan ada 7 proton pada $\delta 4,70 \mathrm{ppm}$ $(1 \mathrm{H}, \mathrm{t}) ; 3,98 \mathrm{ppm}(1 \mathrm{H}, \mathrm{t}) ; 3,71(1 \mathrm{H}, \mathrm{m}) ; 2,47$ $(1 \mathrm{H} d, J=11,25 \mathrm{~Hz}) ; 2,23 \mathrm{ppm}(1 \mathrm{H}, \mathrm{m}) ; 2,03$ $(1 \mathrm{H}, \mathrm{m})$ dan $1,87 \mathrm{ppm}(1 \mathrm{H}, \mathrm{t})$.

Hasil spektra RMI karbon ${ }^{13} \mathrm{C}(125 \mathrm{MHz})$ menunjukkan 7 puncak dimana pada daerah $\delta$ 179,57 ppm menunjukkan adanya karbon kwartener dari C karbonil, adanya puncakpuncak pada $\delta 77,97 ; 73,19 ; 67,42 ; 66,94$ ppm menunjukkan adanya puncak-puncak karbon alkohol skunder dan 2 puncak alkohoh skuder yang sheilding dekat dengan karbonil pada $\delta$ 40,23 dan 37,93 ppm. Dari hasil penelusuran dan prediksi puncak-puncak $\delta^{1} \mathrm{H}$ dan ${ }^{13} \mathrm{C}$ dari Chem Draw, dapat di prediksi bahwa senyawa D tersebut adalah 2,3,4,5,6-pentahidroksi sikloheksan asamkarboksilat.<smiles>O=C(O)C1CC(O)C(O)C(O)C1O</smiles>

(D). 2,3,4,5, -tetrahidroksi

sikloheksan asam karboksilat.

Tabel 5.Data NMR Proton dan Karbon Senyawa D

\begin{tabular}{clc}
\hline No & \multicolumn{1}{c}{$\delta^{l} H($ ppm $)$} & $\delta^{I 3} C($ ppm $)$ \\
\hline 1 & $2,22(1 \mathrm{H}, t)$ & 40,23 \\
2 & $4,70(1 \mathrm{H}, t)$ & 66,94 \\
3 & $3,98(1 \mathrm{H}, t)$ & 77,97 \\
4 & $3,71(1 \mathrm{H}, q)$ & 73,19 \\
5 & $2,47(1 \mathrm{H}, d, J=11,05$ & 67,42 \\
& $\mathrm{~Hz})$ & \\
6 & $1,87(1 \mathrm{H}, t)$ & 37,93 \\
& $2,02(1 \mathrm{H}, q)$ & 179,57 \\
1 & - & \\
\hline
\end{tabular}

\section{KESIMPULAN}

Dari penelitian yang telah dilakukan dapat disimpulkan sebagai berikut:
1) Hasil isolasi kandungan senyawa kimia fraksi $n$-heksana rimpang $C$. barometz diperoleh senyawa metil dodekanoat (metil laurat) (A), $\beta$-sitosterol (B) dan $\beta$-sitosterol -O-glukopiranosida $(\mathbf{C})$.

2) Hasil isolasi kandungan senyawa kimia ekstrak metanol bulu $C$. barometz diperoleh senyawa 2,3,4,5,6-pentahidroksi sikloheksan asam karboksilat (D) dan $\beta$ sitosterol glukopiranosida.

3) Hasil uji antioksidan fraksi etil asetat dan fraksi butanol rimpang $C$. barometz menunjukan aktivitas sedang dengan $\mathrm{IC}_{50}$ berturut-turut 27,53 ppm dan 46,24 ppm. Untuk ekstrak methanol rimpang dan ekstrak metanol bulu $C$. barometz dinyatakan kurang aktif dengan $\mathrm{IC}_{50}$ berturut-turut 183,43 ppm dan 126,10 ppm.

4) Dari hasil uji toksisitas dan antidiabetes ekstrak methanol dan hasil partisi dari ekstrak metanol rimpang dan bulu $C$. barometz dinyatakan kurang aktif.

\section{UCAPAN TERIMAKASIH}

Penelitian ini disokong oleh dana penelitian Program Kompetitif LIPI TA 20132014 melalui Pusat Penelitian Biologi-LIPI dan Program Unggulan LIPI TA 2015 melalui Pusat Penelitian Bioteknologi-LIPI. BKSDA Sumatra Barat telah mendukung penelitian ini dengan mempermudah perijinan koleksi material dan memberikan bantuan teknisi lapang. Kami mengucap terima kasih kepada Destri, M.Si., staf peneliti Kebun Raya Cibodas-LIPI dan para anggota tim teknisi proyek penelitian Cibotium barometz di Lembah Harau, Kec. Harau, Kab. Lima Puluh Kota, Sumatra Barat, yang telah membantu dalam pengumpulan dan penanganan bahan simplisia. Ucapan terimakasih juga disampaikan kepada Lia Meliawati, Pusat Penelitian Kimia-LIPI, yang telah membantu teknis penelitian di laboratorium.

\section{DAFTAR PUSTAKA}

[1] A. R. Smith, K.M. Pryer, E. Schuettpelz, P. Korall, H. Schneider, P. G. Wolf. A classification for extant fern. Taxon 55: 705-731 (2006) 
[2] R. E. Holttum, Cyatheaceae. Flora Malesiana Ser. II. Vol. 1. (2): 165.(1963)

[3] T. Ng. Praptosuwiryo, Cibotium barometz. (L.) J. Smith. In W.P. de Winter and V. B. Amoroso (Eds.) Pp. 79-82. Plant Resources of South-East Asia 15 (2) ( 2003)

[4] T. Ng. Praptosuwiryo, D. O. Pribadi, D. M. Puspitaningtyas, S. Hartini, Inventorying of the tree fern genus Cibotium of Sumatra: Ecology, population size and distribution in North Sumatra. Journal Biodiversities Vol. 12 (4): $204-211$ (2011)

[5] Dalimarta, Setiawan, Atlas Tumbuhan Obat Indonesia Jilid 5. Pustaka Bunda, pp 124 126 (2008)

[6] D. M. Yao (chief editor), Pharmacopoeia Commission of the Ministry of Public Health, P.R. China, A Coloured Atlas of the Chinese Materia Medica Specified in Pharmacopoeia of the People's Republic of China (1995 edition), Guangdong Sciences and Technology Press, Guangzhou. (1996)

[7] M. Ou (chief editor), Chinese-English Manual of Common-used Traditional Chinese, Medicine. Guangdong Science and Technology Press, Guangzhou (1992)

[8] H.-Y. Lai and Y-Y. Lim and S. P. Tan, Antioxydative, Tyrosinase Inhibiting and Antibacterial of leaf extracts from medicinal ferns, Biocsi. Biotechnol. Biochem., $73\left({ }^{\wedge}\right), 1362-1366,(2009)$

[9] H.-Y. Lai and Y-Y. Lim, Antioxidant Properties of Some Malaysian Ferns. 3rd International Conference on Chemical, Biological and Environmental Engineering. IPCBEE IACSIT Press, Singapore. vol.20 Pp. 8-12. (2011)

[10] C. C. Wen, L. F. Shyur, J. T. Jan, P. H. Liang, C. J. Kuo, P. Arulselvan, J. B. Wu, S. C. Kuo, N. S. Yang. Traditional Chinese medicine herbal extracts of Cibotium barometz, Gentiana scabra, Dioscorea batatas, Cassia tora, and Taxillus chinensis inhibit SARS-CoV replication. Journal of Traditional and Complementary Medicine Vol. 1 No. 1: 44-50 (2011)

[11] X. Zhao, Z -X. Wu, Y. Zang, Y - B. Yan, Q. He, P. C. Cao and W. Lei, Anti-
Osteoporosis Activity of Cibotiun barometz Extract on Ovariectomy-induced bone loss in rats. J of Ethnopharmacology, 137, 10831088 (2011)

[12] N-X. Cuong, C-V. Minh, P-V. Kiem, H-T. Huong, N-K. Ban, N-X. Nhiem, N-H. Tung, J-W. Jung, H-j. Kim, S-Y. Kim, J-A. Kim, Y-H.Kim, , J. Nat. Product. Sep; 1673- 1677 (2009)

[13] Q. Wu and X. W. Yang, The constituents of Cibotium barometz and their permeability in the human Caco-2 monolayer cell model. J Ethnopharmacol. Sep 25;125 (3):417-22 (2009)

[14] N. I. Xu, Y. Cao , Y. N. Shi, X. Zhong, T. Z. Jia. New hydrolysable tannin from Cibotium barometz, Zhongguo Zhong Yao Za Zhi. Mar; 38(5):698-702 (2013)

[15] G. Yen and H. Chen, Antioxidant Activity of Various Tea Extracts in Relation to Their Antimutagenicity, J. Agric. Food Chem. 43: 27-32 (1995)

[16] N. Artanti, R. Seksiati, A. F. Rochman, Jamilah, P. D. L. Lotulung, M. Hanafi dan L. B. S. Kardono, Study of an Indonesian Mistletoe, The Dendrophthoe pentandra ( L.) Miq. Grown on Star Fruit and Manggo as host Trees, International Symphosium on Biomedicine, Bogor, September 18-19 (2003)

[17] B. N. Meyer, N. R. Ferrigni, J. E. Putham, L. B. Jacobsen, D. E. Nochols and J. L. McLaughlin, "Brine Shrim A Convenient General Bioassay for Active Plant Constituents Planta Medica", Medical Plant Research Vol 45, Departemen of Medicinal Chemistry and Pharmacognosy, West Lafayett, 31-34 (1992)

[18] L. M. Jerry, C.-J. Chan and D. L. Smith, “ Bioassay For The Discovery of Natural Product : An Update "Workshop On Brine shrim and Potato Disc Bioassay", Universitas Bidang Ilmu Hayati Institut Teknologi Bandung, hal 3-6 (1990)

[19] J. H. Kim, H. J. Kim, H. W., S. H. Youn, D. Y. Choi, C. S. Shin, Development of inhibitory against lipase and $\alpha$-glucosidase fro derivatives of monascus pigmen, FEMS Microbial Lett. 276: 93-98 (2007) 
J.Kim.Terap.Indones., 18(1), pp. 1-10, June 2016
p-ISSN: 0853-2788, e-ISSN: 2527-7669 Accreditation number : 540/AU1/P2MI LIPI/06/2013 